\title{
Optimization of Feeding Efficiency for Cost Effective Production of Penaeus monodon Fabricius in Semi-Intensive Pond Culture System
}

\section{Hasan BMA ${ }^{1}$, Guha $B^{1}$ and Datta $S^{2 *}$}

${ }^{1}$ Netaji Subhas Open University, 1 Woodburn Park, Kolkata, West Bengal, India

${ }^{2}$ Regional Research Station, New Alluvial Zone, Bidhan Chandra Krishi Viswavidyalaya, West Bengal, India

\begin{abstract}
Experiment with four different daily feeding frequencies, i.e., three (T1), four (T2), five (T3) and six times (T4) were conducted with supplementary feed $\left(38 \%\right.$ crude protein) in the earthen ponds $\left(5000 \mathrm{~m}^{2}\right)$ to determine the optimum feeding frequency for cost effective commercial production of Penaeus monodon Fabricius. Post larvae of black tiger shrimp (initial weight $0.02 \pm 0.001 \mathrm{~g}$ ) with stocking density of $20 \mathrm{~m}^{-2}$ were cultured for 110 days to evaluate the growth and production by studying different parameters of feed utilization efficiency as feed conversion ratio (FCR), protein efficiency ratio (PER), feed efficiency ratio (FER), production yield; and adequate growth levels as average body weight (ABW), weight gain (WG), specific growth rate (SGR), and survival of cultured shrimp. During production cycle, various water quality parameters of the ponds were found within normal range for aquaculture except for $\mathrm{NH}_{4}-\mathrm{N}, \mathrm{NO}_{3}-\mathrm{N}$ and $\mathrm{PO}_{4}-\mathrm{P}$ which were significantly lower in $\mathrm{T} 3(\mathrm{p}<0.05,0.01)$ and $\mathrm{PO}_{4}-\mathrm{P}$ in $\mathrm{T} 4(\mathrm{p}<0.05)$ series than T1. After harvest ABW, WG, SGR were significantly higher in T2, T3 and T4 ponds than T1 ( $p<0.05$, 0.001). FCR, FER and PER followed the same pattern $(p<0.05,0.01,0.001)$ in $T 2, T 3$ and T4 series than T1. Finally significantly higher $(p<0.05)$ survival rate $(82.5 \pm 2.9 \%)$ and production yield $\left(4562 \pm 55.2 \mathrm{~kg} \mathrm{ha}^{-1}\right)$ were found in T3 than others, which indicated an additional support towards efficient feeding management and its outcome to T3. Maximized feed utilization and production efficiency with lesser wastage of feed was observed in T3 ponds than other series of ponds. Daily five-time feeding frequency (T3) earned significantly higher net profit of INR. 503233 ha-1 and return on investment (ROI) $69 \%$ compared to other treatments. Substantial improvement in growth and yield with higher profitability from ponds with daily five-time feeding frequency (T3) revealed it as the optimum feeding management for augmenting cost efficient production of P. monodon in a semi-intensive farming system.
\end{abstract}

Keywords: Feeding frequency; Growth; Cost efficient; Penaeus monodon; Yield

\section{Introduction}

In recent years, the culture of Penaeus monondon Fabricius received maximum importance owing to its unique taste, high nutritive value and persistent demand in world market and good profitability. Commercial shrimp farming depends largely upon formulation of high energy balanced feed, which constitutes nearly $55 \%$ of the total operation costs for shrimp culture [1]. Feed management is a key factor affecting water quality and production economics in aquaculture [24]. Failures in shrimp production are mainly due to post larvae (PL) quality, feed, water and soil quality or disease but in most cases origin of problem is poor feed management [5]. However, environmental, social and economic considerations demand the need to improve feed management and feed formulations [6]. Feed is the initial source of pollutants as overfeeding or poor quality feeds can severely affect water quality and production of shrimp [6]. Thus, daily inputs of supplementary feed must be reasonable and should take into account growth of the shrimp as well as nutrient capacity of the pond ecosystem. Supplementary feed in shrimp farming is not only the initial source of physiological wastes, but it accounts for $55-60 \%$ of the operational costs in intensive and $40-50 \%$ in semi-intensive culture system $[7,8]$. It was reported that increased feeding rate beyond the natural carrying capacity of the pond deteriorates the water quality [9]. Out of total feed applied to pond, only $16.7 \%$ (by dry weight) is converted into shrimp biomass, the rest is leached or otherwise not consumed, egested as faeces, eliminated as metabolites, etc. [10]. Negative effects of supplementary feed are not isolated but promote diseases and other water quality related problems which affect production $[2,11]$. Therefore, feed management strategy should be aimed at optimizing feed inputs, reducing feed conversion ratios and the potential impact on the culture and effluent water [11]. Both feed management and quality play important role in governing production and profitability [1]. As frequency of feeding is the main part of management and Smith et al. [12] described that feeding strategy can have a significant impact on pond water quality, growth, health and survival of $P$. monodon which contribute to the profitability of production. Protein is the central to feed formulation system and the most important constituent in prawn nutrition [13]. Minimum dietary protein requirement for P. monodon was reported to $35-50 \%$ [14]. On the other hand, multiple daily feeding and distribution is desirable as shrimp eat slowly and almost continuously [15]. However, increased feeding frequency was reported to reduce nutrient leaching and improves feed utilization efficiency [16]. Feed management has an impact on feed conversion efficiency as well as minimizing pond bottom and water quality deterioration due to over feeding [17].

Impact of feeding frequency inside ponds is not well understood and no clear information is available as farmers usually differ in practice applying feed 2-6 times daily. However, some information on feeding frequency of 2-4 times per day is applicable in shrimp ponds $[1,12,17]$. Although feed intake pattern and consumption rate of shrimp varies

*Corresponding author: Datta S, Regional Research Station, New Alluvial Zone, Bidhan Chandra Krishi Viswavidyalaya, Gayeshpur-741234, Nadia, West Bengal, India, Tel: +913325895851; Fax: +913325895851, E-mail: drsubhendudatta@rediffmail.com

Received June 28, 2012; Accepted August 18, 2012; Published August 28, 2012

Citation: Hasan BMA, Guha B, Datta S (2012) Optimization of Feeding Efficiency for Cost Effective Production of Penaeus monodon Fabricius in Semi-Intensive Pond Culture System. J Aquacult Res Dev 3:149 doi:10.4172/21559546.1000149

Copyright: (c) 2012 Hasan BMA, et al. This is an open-access article distributed under the terms of the Creative Commons Attribution License, which permits unrestricted use, distribution, and reproduction in any medium, provided the original author and source are credited. 
under different agro-climatic conditions, a site-specific standardized feeding program is essential for effective feeding management [1]. Information regarding feed management in shrimp farming is meager from both economic and environmental perspectives. In the present study, same quality and quantity of feed with different feeding frequencies (3-6 times per day) were used in all the experimental ponds. Efficient production of cultured shrimp was determined by estimating feed utilization efficiency (FCR, PER, FER, production yield) and growth level (ABW, WG, SGR and survival). As feed is one of the expensive inputs inside ponds, the demand of maximized feed utilization is the need of the hour and paramount important to shrimp farmers. Thus the aim of present study was to determine the optimum feeding frequency for cost effective production of Penaeus monodon in the brackishwater ponds of West Bengal, India.

\section{Materials and Methods}

\section{Experimental ponds}

Black tiger shrimp, Penaeus monodon Fabricius (1798) was cultured for 110 days between August and December, 2010 in twelve earthen ponds ( 0.5 ha or $5000 \mathrm{~m}^{2}$ each) randomly selected in Kar shrimp farm (Mahishadal, East Medinipur, West Bengal, India; Lat $21^{\circ} 5^{\prime} \mathrm{N}$, Long $88^{\circ} 46^{\prime} \mathrm{E}$ ). Three ponds each were used to culture the shrimp for different feeding frequencies: (i) 3 times (T1), (ii) 4 times (T2), (iii) 5 times (T3), and (iv) 6 times (T4) day ${ }^{-1}$. Ponds were selected for each treatment following the random block design (RBD) [18]. All the experimental ponds were rectangular in shape with facility of both inlet and outlet structures with average of 1.2 meter water depth. Soil was clayey loam and aeration was maintained for all ponds during the culture period.

\section{Rearing in ponds}

Similar pond management practices like sun drying, tilling, liming, and eradication of predators were performed once prior to water filling as described by Hasan et al. [19] in all the experimental ponds during culture. Culture techniques and inputs were same for all ponds of four treatments. The ponds were ploughed conventionally and limed (1.5 ton $\left.\mathrm{ha}^{-1}\right)$ to improve the soil condition alkaline. Initial water filling in ponds was done directly with water pumped from Haldi river creek after being filtered by fine mesh bag net of 300 micron and chlorination (30 ppm with $60 \%$ active ingredients) was done for disinfection and killing of pathogens. After three days of declorination, organic fertilizers (poultry litter@ $250 \mathrm{~kg} \mathrm{ha}^{-1}$ ) and inorganic fertilizers (urea @20 kg ha ${ }^{-1}$; single super phosphate @ $5 \mathrm{~kg} \mathrm{ha}^{-1}$ ) were applied to improve the primary productivity of the cultured ponds. Routine application of urea @6 $\mathrm{kg} \mathrm{ha}^{-1}$ and single super phosphate @2 $\mathrm{kg} \mathrm{ha}^{-1}$ were performed twice a month to maintain development of natural food. Agricultural lime and dolomite each were applied once a month @ $50 \mathrm{~kg} \mathrm{ha}^{-1}$ during production period. No water exchange was done during initial 20 days and later it was limited to $0-10 \%$ in every alternate days from pre-treated reservoir. During raining, only surface draining was maintained to retain salinity. Good quality and disease-free post larvae of 20 days old (PL ) of P. monodon were procured from a private hatchery (Vaisakhi Hatchery, A.P., India), then acclimatized and stocked @ 20 pieces m-2 in all the ponds where water quality were almost in same ranges within aquaculture standard (temperature $28.4-28.6^{\circ} \mathrm{C}$, dissolved oxygen $>4.0$ $\mathrm{mg} \mathrm{l}^{-1}, \mathrm{pH} 7.9-8.1$, Secchi's disc transparency $35-45 \mathrm{~cm}$ and salinity 7-8 $\mathrm{g} \mathrm{l}^{-1}$ ) [20]. Harvesting happened after 110 days of culture as per market demand and good quality of shrimps. A bag net was fitted on outlet canal with 20 \# mesh (pore size) of width 1 meter and length of 4 meter. The water level in the pond was reduced to $60-70 \mathrm{~cm}$ and outlet was opened and shrimp was caught at night, collected with ice and sold to processors on farm-gate price.

\section{Feeding management}

Shrimps were fed with standard commercial palletized feeds (crude protein-38\%, fat-5\%, fiber- $4 \%$, ash-12-15\%, calcium-2.2-2.5\% and phosphorus-1.5-1.8\%) and applied as prescribed by feed company (Chorean Pokhpand-Novo, Chennai, India). The feeding regime (frequency, time of feeding and percentage ration) for cultured shrimp was presented in Table 1. Feeding was administered according to their body weight and days of culture in a fixed quantity in all treatments (Table 2). Small post larvae were fed two times a day (1-15 days) for providing more availability of feed and they are accustomed to feed on natural foods; slowly increased to three times a day as it grows bigger (16-44 days). Later (45-110) feeding was followed as mentioned in Table 2 for the experiment that was pallet feed with more quantity. Feed was broadcasted by rope method, i.e., floats tied and moved with rope in lines horizontally in all ponds [21]. Aeration (4-10 hours as per biomass) was kept off for two hours during feed application.

\section{Evaluation of growth and feed utilization efficiency}

Cast net was used to measure the growth rate of shrimps during early hours. Shrimps were sampled every fortnight by cast net for monitoring the growth, survival and health conditions of shrimp and for estimation of production yield in the experimental ponds. During stocking average weight of post larvae (PL20) was $0.02 \mathrm{gm}$ and the first sampling was taken after 15 days of grow out phase from four locations of each pond. The average body weight (ABW) was measured at fortnightly intervals till harvest. For measuring ABW, 100 samples of shrimp collected by cast net randomly \& mean weight was calculated. For estimation of survival, measured cast net was thrown to ponds randomly 4 times and density calculated as per available shrimps in cast net and total pond area in relation to initial stocking density. FCR (Feed conversion ratio) is calculated as total feed utilized divide by total shrimp yield. Survival, FCR, yield were calculated from 45 days onwards as shrimps were smaller in size. Weight gain (WG), FCR and specific growth rate (SGR) was measured as per conventional method [22] in every fifteen days. Protein efficiency ratio (PER) and feed efficiency ratio (FER) were estimated by routine methods [23,24]; and $\mathrm{ABW}$, survival rate and production yield were calculated following the method of Hasan et al. [19]. Health conditions were recorded during same samplings for gut and abnormalities. Samplings of shrimps were regularly performed every 15 days until harvest. The formulae to calculate different parameters are as follows:

Average body weight $(\mathrm{ABW})=$ Total weight of 100 shrimps (g) / 100 Weight gain $(\mathrm{WG})=$ Final weight $(\mathrm{g})$ - initial weight $(\mathrm{g})$

Food conversion ratio $(\mathrm{FCR})=$ Total feed consumed $(\mathrm{kg}) /$ total yield (kg)

Survival rate $=$ Average no. of shrimps caught/cast net area $\left(\mathrm{m}^{2}\right)$ ×pond area $\left(\mathrm{m}^{2}\right) \times 100 /$ number of post larvae stocked

Specific growth rate $(\mathrm{SGR})=100 \times(\mathrm{Wf}-\mathrm{Wi}) /$ period $($ days $)[\mathrm{Wf}=$ final weight; $\mathrm{Wi}=$ initial weight]

Protein efficiency ratio $($ PER $)=$ Wet weight gain $(\mathrm{g}) /$ Protein fed $(\mathrm{g})$

Feed efficiency ratio $($ FER $)=$ Final weight $(\mathrm{g})$-initial weight $(\mathrm{g}) /$ total feed intake $(\mathrm{g})$ 
Citation: Hasan BMA, Guha B, Datta S (2012) Optimization of Feeding Efficiency for Cost Effective Production of Penaeus Monodon Fabricius in Semi-Intensive Pond Culture System. J Aquacult Res Dev 3:149 doi:10.4172/2155-9546.1000149

Page 3 of 7

Production yield=Survived shrimps number $\mathrm{x}$ ABW

\section{Water characteristics}

Different water quality parameters like temperature, dissolved oxygen, $\mathrm{pH}$ were monitored twice a day (6-00 and 16-00 hrs); salinity and transparency once a week (11-00 hours) in situ at farm site by multiparameter device YSI, MP556 mode and secchi disc. Other nutrient parameters $\left(\mathrm{NH}_{4}-\mathrm{N}, \mathrm{NO}_{3}-\mathrm{N}, \mathrm{PO}_{4}-\mathrm{P}\right)$, total alkalinity were monitored in monthly intervals during the production cycle $[2,25]$.

Economic analysis: Production costs, net profit, benefit cost ratio (BCR) and return on investment (ROI) were calculated as method described by Hari et al. [24].

Statistical analysis: Data obtained from the results were subjected to statistical analysis. One-way analysis of variance (ANOVA) was done with the help of computer software SPSS (version 7.5) and the sample means compared [18]. For the analysis of data, student's t test was conducted between data of T1 (lowest feeding frequency) with other series and to test the level of significance the Fisher and Yates statistical tables were used [26].

\section{Results}

\section{Water quality parameters}

There were no significant differences in physical parameters such as temperature, salinity, transparency, $\mathrm{pH}$, dissolved oxygen (DO) among treatments and they were all at optimum level for $P$. monodon culture (Table 3). Although DO level (morning) before feeding at the last part of culture period in $\mathrm{T} 1$ and $\mathrm{T} 4$ showed lesser value than others but afternoon DO levels were higher than morning in all days throughout the culture in all treatments (Figure 1). However, the concentration of nutrient parameters (ammonium- $\mathrm{N}$, nitrate- $\mathrm{N}$, and orthophosphate) varied with the feeding frequency in the cultured ponds. The level of nitrate- $\mathrm{N}$ and ammonium- $\mathrm{N}$ in $\mathrm{T} 3$ pond was found significantly reduced than $\mathrm{T} 1$ ponds $(\mathrm{p}<0.05,0.01)$. On the other hand, the amount of orthophosphate reduced significantly $(\mathrm{p}<0.05,0.01)$ in both the T3 and $\mathrm{T} 4$ ponds than $\mathrm{T} 1$ ponds during the culture period. Total alkalinity across the treatment ponds ranging between 113-122 $\mathrm{mg} \mathrm{l}^{-1}$ was not significantly different $(\mathrm{p}>0.05,0.01)$.

\section{Growth and feed utilization efficiency}

ABW, WG, SGR and survival were used to evaluate the growth performance of cultured shrimp with the frequency of feed applied in different cultured ponds. Initial SGR of $P$. monodon was almost same (9.7-11.6\%) in all the ponds which increased steadily between DOC 6075 in all ponds and it was higher in T3 ponds. After DOC 75, it reduced and collapsed after 90 days (11.3\%) till harvest (Figure 2). It was also found that average body weight (ABW) of $P$. monodon increased as culture time progressed in all ponds. At harvest, the highest ABW was observed in T3 $(27.67 \pm 0.26 \mathrm{~g})$ followed by T2 $(26.3 \pm 0.27 \mathrm{~g})$, $\mathrm{T} 4(24.17 \pm 0.23 \mathrm{~g})$ and $\mathrm{T} 1(22.9 \pm 0.2 \mathrm{~g})$ (Figure 3). While comparing the growth data of $\mathrm{T} 1$ pond with that of other treatment ponds it was

\begin{tabular}{|l|l|c|c|}
\hline $\begin{array}{l}\text { Treat- } \\
\text { ment }\end{array}$ & $\begin{array}{l}\text { Feeding } \\
\text { frequency } \\
\text { (times } \\
\text { day }^{-1} \text { ) }\end{array}$ & $\begin{array}{c}\text { Time of feeding } \\
\text { (daily) }\end{array}$ & $\begin{array}{c}\text { Amount of feed } \\
\text { ration } \\
(\% \text { daily) }\end{array}$ \\
\hline T1 & Three & $7: 00,15: 00,20: 00$ & $35,30,35$ \\
T2 & Four & $7: 00,11: 00,15: 00,20: 00$ & $30,20,30,20$ \\
T3 & Five & $6: 00,10: 00,14: 00,8: 00,22: 00$ & $20,20,20,20,20$ \\
T4 & Six & $5: 00,8: 00,11: 00,15: 00,18: 00,22: 00$ & $20,15,15,15,20,15$ \\
\hline
\end{tabular}

Table 1: Feeding regime in different frequencies in experimental ponds of $P$. monodon.

\begin{tabular}{|l|l|l|l|l|}
\hline DOC & Feed type & Feed size $(\mathrm{mm})$ & $\begin{array}{l}\text { \% of Body Weight } \\
(\min .-\max .)\end{array}$ & $\begin{array}{l}\text { Quantity(kg) } \\
\text { min. - max. })\end{array}$ \\
\hline $1-15$ & Crumble & $0.42-0.89$ & $10-15$ & $4-14$ \\
$16-44$ & Crumble & 1.41 & $5.5-8.5$ & $16-50$ \\
$45-70$ & Pallet & $1.8 \times 3.5$ & $3.4-5.4$ & $53-65$ \\
$71-110$ & Pallet & $2.3 \times 3.5$ & $2.5-3.2$ & $69-92$ \\
\hline
\end{tabular}

Table 2: Feed and feeding schedule adopted during production period of 110 days (quantity as per DOC and body weight \%).

\begin{tabular}{|c|c|c|c|c|c|}
\hline Variable & $\begin{array}{c}\text { T } 1 \\
\text { (3 times) }\end{array}$ & $\begin{array}{c}\text { T } 2 \\
\text { (4 times) }\end{array}$ & $\begin{array}{c}\text { T } 3 \\
\text { (5 times) }\end{array}$ & $\begin{array}{c}\mathbf{T} \mathbf{4} \\
\text { (6 times) }\end{array}$ & $\begin{array}{c}\text { Optimum } \\
\text { range }\end{array}$ \\
\hline $\begin{array}{l}\text { Temperature } \\
\left({ }^{\circ} \mathrm{C}\right)\end{array}$ & $25.92 \pm 2.32$ & $25.86 \pm 2.67$ & $25.91 \pm 2.33$ & $25.93 \pm 2.33$ & $27-33^{*}$ \\
\hline Salinity $\left(\mathrm{g} \mathrm{l}^{-1}\right)$ & $12.5 \pm 2.78$ & $11.71 \pm 2.4$ & $12.33 \pm 2.52$ & $12.49 \pm 2.53$ & $10-30^{*}$ \\
\hline $\begin{array}{l}\text { Transpar- } \\
\text { ency }(\mathrm{cm})\end{array}$ & $53.75 \pm 7.75$ & $51.2 \pm 8.04$ & $45.1 \pm 4.78$ & $43.02 \pm 8.92$ & $30-40^{* *}$ \\
\hline $\mathrm{pH}$ & $7.94 \pm 0.10$ & $7.95 \pm 0.10$ & $7.93 \pm 0.10$ & $7.96 \pm 0.11$ & $7.5-9.0^{* * *}$ \\
\hline $\begin{array}{l}\text { Dissolved } \\
\text { Oxygen (mg } \\
\left.\mathrm{I}^{-1}\right)\end{array}$ & $3.58 \pm 0.56$ & $3.55 \pm 0.64$ & $3.70 \pm 0.63$ & $3.69 \pm 0.63$ & $4.0-8.5^{*}$ \\
\hline $\begin{array}{l}\text { Nitrate-N } \\
\left(\mathrm{mg} \mathrm{l}^{-1}\right)\end{array}$ & $0.73 \pm 0.2$ & $0.45 \pm 0.07$ & $0.44 \pm 0.06 a$ & $0.58 \pm 0.09$ & $<1$ * \\
\hline $\begin{array}{l}\text { Ammonium- } \\
\mathrm{N}\left(\mathrm{mg} \mathrm{l}^{-1}\right)\end{array}$ & $0.18 \pm 0.03$ & $0.14 \pm 0.02$ & $0.08 \pm 0.01 b$ & $0.12 \pm 0.06$ & $<0.1^{* * *}$ \\
\hline $\begin{array}{l}\text { Ortho- } \\
\text { phosphate } \\
\left(\mathrm{mg} \mathrm{l}^{-1}\right)\end{array}$ & $0.11 \pm 0.02$ & $0.07 \pm 0.01$ & $0.04 \pm 0.01 b$ & $0.06 \pm 0.01 a$ & NA \\
\hline $\begin{array}{l}\text { Total Alkalin- } \\
\text { ity }\left(\mathrm{mg} \mathrm{l}^{-1}\right)\end{array}$ & $113.0 \pm 20.7$ & $114.2 \pm 16.3$ & $122.2 \pm 20.3$ & $115.0 \pm 17.4$ & $40-160^{*}$ \\
\hline
\end{tabular}

$a, b$, in the same row with different superscripts are significantly different. $p$ values: ${ }^{a}<0.05 ;{ }^{b}<0.01$; Values in each row with no superscript are non-significant. Sources:

*Fast and Lester, 1992 [37]; **Abesamis, 1989 [38]; ***Tsai, 1989 [39]; NA= not available

Table 3: Water quality characteristics in feed trial ponds (Mean \pm SE of 3 ponds each).

found that WG and SGR have similar pattern of increment and become significant $(\mathrm{p}<0.05,0.001)$ (Table 4). FCR increased in all treatment ponds as time progresses (Figure 4). FCR value was lowest $(1.31 \pm$ $0.02)$ in T3 ponds followed by T2 $(1.48 \pm 0.03), \mathrm{T} 4(1.7 \pm 0.04)$ and highest in T1 $(1.86 \pm 0.11)$. The FCR was found to be reduced as the feeding frequency in cultured ponds increased but it was significant for $\mathrm{T} 2$ and T3 $(\mathrm{p}<0.01)$. On the contrary, a reverse result was obtained in case of PER and FER which was found significant in T2 and T3 pond when compared with T1 $(\mathrm{p}<0.05,0.01,0.001)$ (Table 5). However, the survival of cultured shrimp was higher in all the cultured ponds than $\mathrm{T} 1$ but it was significant for T3 pond $(\mathrm{p}<0.05)$ (Figure 5 and Table 4$)$. Mean survival rate was highest $(82.5 \%)$ in T3 ponds, followed by T2 (77.2\%) and T4 (73.0\%) and T1 (70.5\%) ponds (Figure 5 and Table 4). FCR, PER, FER, daily biomass increment and yield of cultured shrimp in different ponds were presented in Table 5 . In case of daily biomass increment, significantly $(\mathrm{p}<0.01,0.001)$ higher result was obtained in $\mathrm{T} 2$ and T3 ponds than T1. After 110 days of culture, highest yield (4562 $\mathrm{kg} \mathrm{ha}^{-1}$ ) was obtained in T3 ponds followed by T2 ponds $\left(4058 \mathrm{~kg} \mathrm{ha}^{-1}\right)$. In other two ponds (T1 and T4) the production was relatively lower than T2 and T3 (Figure 6 and Table 5). Protein efficiency ratio (PER) in this study was 2.0 in T3 pond followed by T2 (1.75), T4 (1.55) and T1 (1.42). Feed efficiency ratio (FER) value obtained highest in T3 ponds (0.76) and lowest (0.54) in T1 ponds (Table 4).

\section{Economic analysis}

Production yield $\left(\mathrm{kg} \mathrm{ha}^{-1}\right)$ at harvest was significantly higher $(\mathrm{p}<0.01,0.001)$ in T2 and T3 than T1 (Table 5, Table 6). The feed application of four and five times day 1 had a significant effect $(\mathrm{p}<0.05$, 0.01 ) on the gross revenue (INR. 1055080 and 1231740) from the 

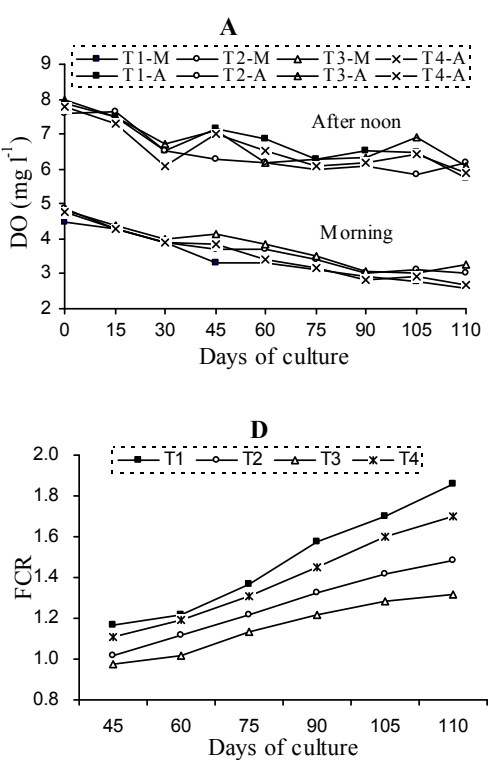

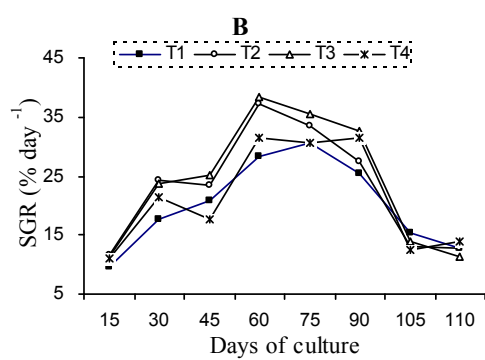

E

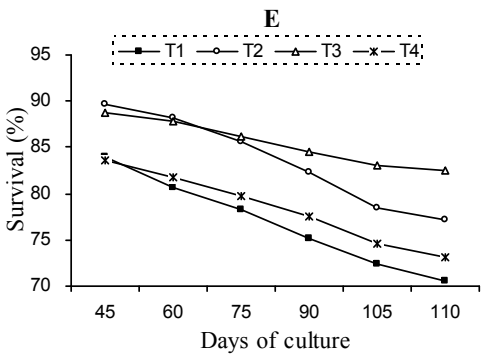

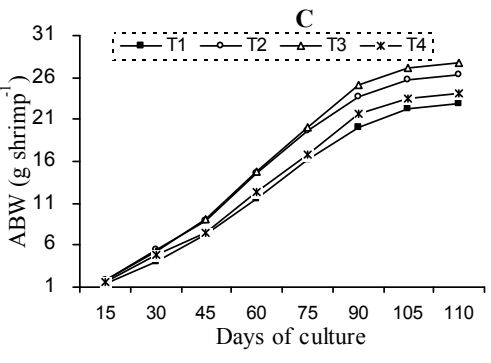

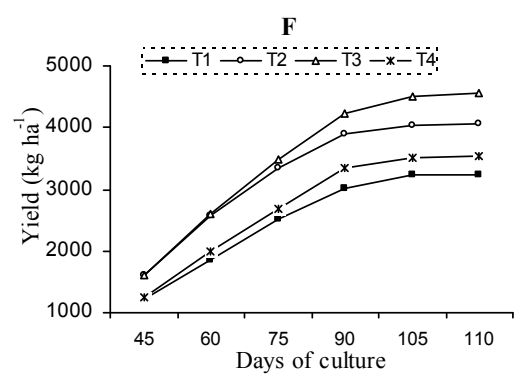

Figure 1: The effect of different feeding frequencies on growth and feed utilization efficiency in ponds stocked with $P$. monodon. T1:3 times, T2:4 times, T3-5 times, T4-6 times feeding day ${ }^{-1}$; $M=$ morning $D O, A=$ afternoon $D O$.

harvested shrimp $\left(\mathrm{ha}^{-1}\right)$ of $\mathrm{T} 2$ and $\mathrm{T} 3$ respectively than T1. Net profit and benefit cost ratio (BCR) among the treatments followed the significance same as gross revenue. Significantly higher BCR (0.69) in ponds with five feeding frequency as compared to others amply speaks for effective net profit (INR. 503233) and return on investment (69\%) after the harvest of 110 days of culture period (Table 6). Production cost was found to be higher as the feeding frequency increases (INR. 1500 frequency ${ }^{-1}$ ) due to involvement of additional laborers for every higher feeding frequency.

\section{Discussion}

In the present study it is found that feeding frequency has a profound influence on cost effective production of $P$. monodon. There was no effect on changes of water quality parameters for feeding frequencies in different treatment ponds as earlier finding [12], although some nutrients were on higher level in T1 and T4 and all parameters were within optimum ranges (Table 3). Fluctuation of DO in all treatment ponds was almost same although slightly higher DO ( $>0.05$ ) observed in T3 ponds in morning and afternoon (Figure 1) than others. Different growth and feed efficiency parameters have been found to be modulated by changed feeding frequency although feed constituents, feed amount and distribution were similar in all the culture ponds. SGR increased steadily between 60-75 DOC in all ponds but the maximum value of SGR $(38.4 \%)$ in T3 ponds was observed in DOC 60 with gradual declining trend thereafter (Figure 2) corroborated the previous finding [27]. This may be due to the fact that larval shrimp generally depend on planktonic food at the early stage, after which they gradually acclimatize to the supplementary feed [26]. At harvest, the highest ABW was observed in T3 (27.67 $\pm 0.26 \mathrm{~g})$ and lowest in T1 (22.9 $\pm 0.2 \mathrm{~g})$ (Figure 3). Previous study found almost similar (T3) growth $(29.24 \pm 1.4 \mathrm{~g})$ pattern for $40 \%$ protein feed in 120 days of culture [27]. Therefore, it can be substantiated that decline in temperature below $25^{\circ} \mathrm{C}$ could decrease feed consumption and growth rate [28], thus lower temperature at the end of culture $\left(22.1^{\circ} \mathrm{C}\right)$ in ponds caused poor consumption of feed and was responsible for slow growth rate of shrimp. However, ideal water stability ensures better feed consumption and good pond bottom and water quality [20]. As shrimp live on or near to bottom of pond, higher concentration of $\mathrm{NH}_{4}-\mathrm{N}$ and $\mathrm{NO}_{3}-\mathrm{N}$ found in $\mathrm{T} 1$ and $\mathrm{T} 4$ ponds affected the health, feed intake and growth; and possibly lower survival [29]. Lower level of orthophosphate in T3 ponds was found to be suitable for good growth of shrimp. Matias et al. [20] observed that this was happened as a result of less feed wastes which can be substantiated by lower FCR value in these ponds (Table 5). Furthermore, feed pellets that are known to disintegrate faster in water facilitate only economic loss and pollution of water [30]. Thus, frequent occurrence of black soil formation in T1 and T4 ponds causing gills choking due to accumulation of feed wastes (unconsumed) resulted in higher FCR that showed clear temporal variation during the culture period and this increased as time progressed (Figure 4). FCR value was found lowest $(1.31 \pm 0.02)$ in $\mathrm{T} 3$ pond and highest in T1 $(1.86 \pm 0.11)$. Feed is one of the essential inputs in shrimp production and decides for profitability. The cost of labor for feeding of shrimp ponds can be a significant component of the fixed costs [31] as found in this study (Table 6). However, moderate feed inputs of 2-4 times per day (depending on shrimp size) are often recommended for better growth $[1,12,17]$. From the present result it is clear that feeding of five times a day in T3 ponds fetched best net profit and BCR (Table 6) amongst all treatments. Feed conversion improves with increasing feeding frequency [23] but the interesting feature of the study is that FCR improves for 5- time feeding frequency (T3) but not for further increment of frequency (T4) (Figure 4 and Table 5). Protein being the most important and expensive nutrient in shrimp feed, nutritionally well-balanced diet is important for profit [5]. The best value observed for protein efficiency ratio (PER) in this study was 2.0 as almost similar value of 2.55 was reported in ponds feeding with same protein content [34]. Thus, five times feeding is the best to utilize the protein conversion to shrimp as found in this study. In this study highest Feed efficiency ratio (FER) in T3 ponds (0.76) indicated maximum utilization of feed for 5 times feeding and it is more improved than earlier finding (0.47) [35]. In the present study, black tiger shrimp achieved highest growth (ABW, WG and SGR) from same diet with 5 times feeding frequency (Table 4). 
Citation: Hasan BMA, Guha B, Datta S (2012) Optimization of Feeding Efficiency for Cost Effective Production of Penaeus Monodon Fabricius in Semi-Intensive Pond Culture System. J Aquacult Res Dev 3:149 doi:10.4172/2155-9546.1000149

Page 5 of 7

\begin{tabular}{|c|c|c|c|c|}
\hline Variable & $\begin{array}{c}\text { T1 } \\
\text { (3 times) }\end{array}$ & $\begin{array}{c}\text { T2 } \\
\text { (4 times) }\end{array}$ & $\begin{array}{c}\text { T3 } \\
\text { (5 times) }\end{array}$ & $\begin{array}{c}\text { T4 } \\
\text { (6 times) }\end{array}$ \\
\hline $\begin{array}{l}\text { ABW }(g) \\
\text { WG }(g) \\
\text { SGR }\left(\% \text { day }^{-1}\right) \\
\text { Survival }(\%)\end{array}$ & $\begin{array}{c}22.9 \pm 0.20 \\
22.88 \pm 0.20 \\
20.8 \pm 0.31 \\
70.5 \pm 4.1\end{array}$ & $\begin{array}{c}26.3 \pm 0.27^{c} \\
26.28 \pm 0.26^{c} \\
23.9 \pm 0.24^{c} \\
77.2 \pm 2.9\end{array}$ & $\begin{array}{c}27.67 \pm 0.26^{c} \\
27.64 \pm 0.26^{c} \\
25.1 \pm 0.23^{c} \\
82.5 \pm 2.91^{a}\end{array}$ & $\begin{array}{c}24.17 \pm 0.23 \\
24.14 \pm 0.23^{a} \\
21.9 \pm 0.21^{a} \\
73.0 \pm 4.52\end{array}$ \\
\hline
\end{tabular}

a, b, c in the same row with different superscripts are significantly different. p values: $a<0.05 ; b<0.01$; $c<0.001$. Values in each row with no superscript are non-significant Table 4: Variations of different growth parameters after harvest.

\begin{tabular}{|c|c|c|c|c|}
\hline Variable & $\begin{array}{l}\text { Variable } \\
\text { (3 times) }\end{array}$ & $\begin{array}{c}\text { T2 } \\
\text { (4 times) }\end{array}$ & $\begin{array}{c}\text { T3 } \\
\text { (5 times) }\end{array}$ & $\begin{array}{c}\text { T4 } \\
\text { (6 times) }\end{array}$ \\
\hline $\begin{array}{l}\text { FCR } \\
\text { PER } \\
\text { FER } \\
\text { Increase in biomass } \\
\left(\mathrm{kg} \mathrm{d}^{-1} \mathrm{ha}^{-1}\right) \\
\text { Yield }\left(\mathrm{kg} \mathrm{ha}^{-1}\right)\end{array}$ & $\begin{array}{l}1.86 \pm 0.11 \\
1.42 \pm 0.05 \\
0.54 \pm 0.02 \\
29.35 \pm 1.0 \\
3229 \pm 112.9\end{array}$ & $\begin{array}{c}1.48 \pm 0.03^{b} \\
1.75 \pm 0.06^{a} \\
0.67 \pm 0.01^{b} \\
36.89 \pm 0.73^{b} \\
4058 \pm 80.5^{b}\end{array}$ & $\begin{array}{c}1.31 \pm 0.02^{b} \\
2.0 \pm 0.02^{c} \\
0.76 \pm 0.01^{c} \\
41.47 \pm 0.45^{c} \\
4562 \pm 55.2^{c}\end{array}$ & $\begin{array}{c}1.7 \pm 0.04 \\
1.55 \pm 0.04 \\
0.59 \pm 0.02 \\
32.07 \pm 0.87 \\
3528 \pm 95.5\end{array}$ \\
\hline
\end{tabular}

$a, b, c$ in the same row with different superscripts are significantly different. p values: $a<0.05 ; b<0.01 ; c<0.001$. Values in each row with no superscript are non-significant Table 5: Variations of different feed efficiency parameters in different treatments.

\begin{tabular}{|c|c|c|c|c|}
\hline Particulars & $\begin{array}{l}\text { T1 } \\
\text { (3 times) }\end{array}$ & $\begin{array}{l}\text { T2 } \\
\text { (4 times) }\end{array}$ & $\begin{array}{l}\text { T3 } \\
\text { (5 times) }\end{array}$ & $\begin{array}{l}\text { T4 } \\
\text { (6 times) }\end{array}$ \\
\hline \multicolumn{5}{|l|}{ Variable costs } \\
\hline $\begin{array}{l}\text { Pond preparation } \\
\text { (Lime, tilling, disinfection) }\end{array}$ & 16500 & 16500 & 16500 & 16500 \\
\hline Fertilizers and chemicals & 8200 & 8200 & 8200 & 8200 \\
\hline Fry(200000@INR 50/thousand) & 150000 & 150000 & 150000 & 150000 \\
\hline Feed (5989.4 kg @ INR 63/kg) & 377332 & 377332 & 377332 & 377332 \\
\hline Fuel and electricity & 5600 & 5600 & 5600 & 5600 \\
\hline Repair \& maintenance & 8600 & 8600 & 8600 & 8600 \\
\hline Salary \& wages & 24000 & 25500 & 27000 & 28500 \\
\hline Harvesting & 5400 & 5400 & 5400 & 5400 \\
\hline Miscellaneous & 6200 & 6200 & 6200 & 6200 \\
\hline Total variable cost & 601832 & 603332 & 604832 & 606332 \\
\hline $\begin{array}{l}\text { Interest on variable cost } \\
(4 \text { months @13\% p.a.) }\end{array}$ & 26079 & 26144 & 26209 & 26274 \\
\hline \multicolumn{5}{|l|}{ Fixed costs } \\
\hline $\begin{array}{l}\text { Depreciation @ } 10 \% \text { of capital cost (Capital } \\
\text { cost INR 680000) }\end{array}$ & 68000 & 68000 & 68000 & 68000 \\
\hline $\begin{array}{l}\text { Interest on capital cost } \\
\text { (4 months @13\% p.a.) }\end{array}$ & 29466 & 29466 & 29466 & 29466 \\
\hline \multicolumn{5}{|l|}{ Production } \\
\hline Total shrimp yield $\left(\mathrm{kg} \mathrm{ha}^{-1}\right)$ & 3229 & $4058^{b}$ & $4562^{c}$ & 3528 \\
\hline Price of shrimp (INR kg-1) & 245 & 260 & 270 & 250 \\
\hline \multicolumn{5}{|l|}{ Economic analysis } \\
\hline Total production costs (INR) & 725377 & 726942 & 728507 & 730072 \\
\hline Gross revenue (INR) & 791105 & $1055080^{a}$ & $1231740^{\mathrm{b}}$ & 882000 \\
\hline Net profit (INR) & 65728 & $328138^{a}$ & $503233^{b}$ & 151928 \\
\hline Benefit /cost ratio (BCR) & 0.09 & $0.45^{\mathrm{a}}$ & $0.69^{b}$ & 0.21 \\
\hline Return on investment (ROI) & $9.0 \%$ & $45 \%$ & $69 \%$ & $21 \%$ \\
\hline
\end{tabular}

$\mathrm{a}, \mathrm{b}, \mathrm{c}$ in the same row with different superscripts are significantly different. $\mathrm{p}$ values: $a<0.05 ; \mathrm{b}<0.01 ; \mathrm{c}<0.001$. Values in each row with no superscript are non-significant Table 6: Cost (in INR.*) and economic analysis of $P$. monodon on-farm trial in different feeding frequencies (per hectare).

*1 US \$=49.2 Indian Rupees (INR).

Highest survival rate (mean 82.5\%) in T3 ponds with 5 feeding frequencies and lowest in $\mathrm{T} 1(70.5 \%)$ ponds with three feeding frequency was observed (Figure 5 and Table 4). An average survival of 70 to $80 \%$ is quite possible if the ideal condition is maintained for $P$. monodon [32]. It indicates that five times feeding reduced cannibalism (during molting and natural mortality) because gut evacuation is completed in about 3 hours for penaeid shrimps as a way to reduce or eliminate excess uneaten feed waste, which might have happened in $\mathrm{T} 4$.
And in T1 and T2, less feeding frequency might induce cannibalistic behavior of shrimps as feed availability was not enough throughout the day [33]. As survival and growth was better in T3, production yield was substantially higher in ponds with five feeding frequency than other treatments (Figure 6 and Table 5). Less frequent feeding in T1 (3 times) and more frequent feeding in T4 (6 times) significantly limited ABW, WG, SGR, FCR, PER and FER in comparison to T3 and T2 ponds (Table 4, Table 5). This study was not corroborated with the findings 
$[1,12,17]$ for two to four feeding frequency for achieving better growth and yield. Although similar result was found elsewhere [15] where feed conversion and production increased with feeding frequency but sealed to five feedings day ${ }^{-1}$ in this study. In both the cases (T1 and T4), feed quantity might have been wasted more as reflected in pond sediments (black soil) and deterioration in water quality (nutrients) higher than T3.

The realistic economic analysis performed in the on-farm trial showed five feeding frequency substantially increased net profit and return on investment when compared to other frequencies of feeding. Furthermore, the combined effect of higher shrimp yield, bigger size and better market price of shrimps in this frequency significantly increased the gross revenue and net profit. Thus five feedings day ${ }^{-1}$ in commercial ponds of black tiger shrimp has optimized production and profitability with less wastage of feed.

The present study has developed maximized production efficiency, reducing feed wastage and no deterioration of water quality as observed in T3 ponds. Lesser or higher than five times feeding day ${ }^{-1}$ showed comparatively lesser growth and poor economic benefit. Thus, in a semi-intensive shrimp culture system, five-time feeding frequency was the most efficient and cost effective feeding management technique that resulted in highest production yield with better economic benefit and business stability to farmers and stakeholders.

\section{Acknowledgement}

The authors are grateful to Mr. Biswadev Kar, proprietor of the farm (M/S. Kar Shrimp Farm) for providing the ponds with all logistics and inputs in time for the study. They are thankful to the technicians for data recording and supporting during sample collection and analysis.

\section{References}

1. Mohanty RK (2001) Feeding management and waste production in semiintensive farming of Penaeus monodon (Fab.) at different stocking densities. Aquaculture International 9: 345-355.

2. Boyd CE, Tucker CS (1998) Pond Aquaculture Water Quality Management Kluwer Academic Publisher, Boston, Massachusetts, USA.

3. Jory DE (1995) Feed management practices for a healthy pond environment. In Browdy CL, Hopkins JS (Eds.). Swimming through troubled water, proceedings of the special session on shrimp farming. World Aquaculture Society, Baton Rouge, LA, 118-143.

4. Jolly CM, Clonts HA (1993) Economics of Aquaculture. Food Product Press, Binghamton, New York, USA

5. Piadad-Pascual F (1993) Aquafeeds and feeding strategies in the Philippines In: MB New, AGJ Tacon, and I Csavas (Eds.). Farm-made aqua feeds. Proceeding of the FAO/AADCP, Bangkok, Thailand, 317-343.

6. Davis DA, Elkin A, Jesus V, Oscar Z, David BR (2006) A case study on Feed management to improving production and economic returns for the semiintensive pond production of L. vannamei. In: Elizabeth L, Marie DR, Salazar MT, Lopez MGN, et al., (Eds.) Advances en Nutrition acuicola VIII, Universiadad autonoma de Nuevo Leon, Mexico.

7. Chanratchakool P, Turnbull JF, Funge-Smith S, Limsuwan C (1994) Health management in shrimp ponds. Aquatic animal health research institute, Dept. of Fisheries, Kasetsart University, Bangkok, Thailand.

8. Lovell T (1998) Nutrition and Feeding of Fish. Kluwer Academic Publishers, Norwell, Massachusetts.

9. Cole BA, Boyd CE (1986) Feeding rate, water quality, and channel catfish production in ponds. The Progressive Fish- Culturist 81: 25-29.

10. Primavera JH (1993) A critical review of Shrimp pond culture in the Philippines. Reviews in Fisheries Science 1: 151-201.

11. Jory D, Cabrera T, Drugger D, Fegan D, Evans L (2001) A global review of shrimp feed management: status and perspectives, Aquaculture 2001, the annual international conference and exhibition of the world aquaculture society, Orlando, Florida, USA, pp. 318

12. Smith DM, Bufford MA, Tabrett SJ, Irvin SJ, Ward L (2002) The effect of feeding frequency on water quality and growth of the black tiger shrimp (Penaeus monodon). Aquaculture 207: 125-136

13. Colvin PM (1976) Nutritional studies on penaeid prawns: Protein requirements in compounded diets for juvenile Penaeus indicus (Mline Edwards). Aquaculture 7: 315-326.

14. Lim C, Akiyama DM (1995) Nutrient requirements of Penaeid shrimp. In: Lim C, Sessa Dj (Eds) Nutrition and utilization technology in aquaculture. AOCS Press, Champaign, USA. 60-73.

15. Lovett DL, Felder DL (1990) Ontogeny of kinematics in the gut of the white shrimp Penaeus setiferus (Decapoda: Penaeidae). J Crusta Biolo 10: 53-68.

16. Nunes AJP, Parsons GJ (2000) Size-related feeding and gastric evacuation measurements for the Southern brown shrimp Penaeus subtilis. Aquaculture 187: 133-151.

17. Wyban JA, Sweeney JN (1991) Intensive shrimp production technology: the oceanic Institute shrimp manual, USA

18. Gomez AA, Gomez ZA (1984) Statistical Procedures for Agricultural Research ( ${ }^{\text {nd }}$ edn), New York, Chichester, 680.

19. Hasan BMA, Guha B, Dutta S (2011) Salinity mediated growth responses of Penaeus monodon cultured in two different coastal-saline zones of India. Environment and Ecology 29 : 2023-2027.

20. Matias HB, Yusoff FM, Shariff M, Azhar O (2002) Effects of commercia microbial products on water quality in tropical shrimp culture ponds. Asian Fisheries Science 15: 239-248.

21. Soundarapandian P, Sankar S (2008) Effect of probiotics on the survival and production of Black tiger shrimp Penaeus monodon (Fabricius). Int J Zoolo Res 4: 35-41.

22. Ricker WE (1979) Growth rates and models. In: Hoar WS, Randall DJ and Brett JR (Eds) Fish physiology, Academic press, New York, USA, pp: 677-743.

23. Goddard S (1996) Feed management in intensive aquaculture. Chapman and Hall, New York.

24. Hari B, Kurup BM, Varghese JT, Schrama JW, Verdegem MCJ (2004) Effects of carbohydrate addition on production in extensive shrimp culture systems. Aquaculture 241: 179-194

25. APHA (1995) Standard Methods for the Examination of Water and waste Water APHA, Washington, DC., USA.

26. Fisher RA, Yates $F$ (1963) Statistical tables for biological, agricultural and medical research $\left(6^{\text {th }}\right.$ edn $)$. Edinburgh Oliver and Boyd.

27. Mahmood S, Ali MS, Hossain ML (2005) Growth of black tiger shrimp, Penaeus monodon on fishmeal based formulated diet in a southeastern coastal shrimp farm of Bangladesh. Pakistan J Zool 37: 95-100.

28. Saha SB, Bhattacharyya SB, Chowdhury A (1999) Preliminary observation on culture of Penaeus monodon in low-saline waters In: The ICILARM Quarterly Bangladesh.

29. Fox J, Treece GD (1999) Shrimp nutrition and feed management. Texas A \& M University.

30. Millamena OM (1990) Organic pollution resulting from excess feed and metabolites build-up: Effect on Penaeus monodon post larvae. Aquaculture Engineering 9: 143-150.

31. Forster JRM (1972) Studies on the development of compounded diets fo prawns. Proc First Intl Conf Aquacult. Nutr. Delaware, NOAA, 229-248.

32. Lawrence AL, Lee PG (1997) Research in the Americas. In: D'Abramo LR, Conklin DE, Akiyama DM (Eds.). Crustacean Nutrition. Advances in World Aquaculture, vol. 6, WAS, Baton Rouge, pp. 566-587.

33. Nair RJ, Sridhar M (2003) Optimum ration size and feeding frequency fo postlarval Penaeus indicus (H. Milne Edwards). J Mar Biol Ass India 45: 186 194 
Citation: Hasan BMA, Guha B, Datta S (2012) Optimization of Feeding Efficiency for Cost Effective Production of Penaeus Monodon Fabricius in Semi-Intensive Pond Culture System. J Aquacult Res Dev 3:149 doi:10.4172/2155-9546.1000149

34. Shiau SY, Hwang JY (1994) The dietary requirement of juvenile grass shrimp (Penaeus monodon) for Vitamin D. J Nutr 124: 2445-2450.

35. Reddy R (2000) Culture of the tiger shrimp Penaeus monodon (Fabricius) in low saline waters. M.Sc. thesis, Annamalai University, 31.

36. Beseres JJ, Lawrence AL, Feller RJ (2005) Variation in fiber, protein, and lipid content of shrimp feed- effects on gut passage times measured in the field. $\mathrm{J}$ Shellfish Res 24: 301-308.
37. Fast AW, Lester LJ (1992) Marine shrimp culture: Principles and practices. Amsterdam, Elsevier, 862.

38. Abesamis GC (1989) Philippine shrimp grow out practices. In: Proceeding of the Southeast Asia shrimp farm management workshop. Akiyama DM (Ed) American Soybean Association, Singapore, 93-101.

39. Tsai CK (1989) Water quality management. In: Proceeding of the Southeast Asia shrimp farm management workshop. Akiyama DM (Ed) American Soybean Association, Singapore, 56-63. 